\title{
My Radical Dad
}

\author{
Thai Jones
}

The hardest thing for me is to picture my dad as he was in the late 1960s. In those days, Jeff Jones was a leader of the radical and violent Weathermen. He wore blue jeans and a leather jacket. His neck-length blond hair was slicked back in a greaser's ducktail. He was notorious, intimidating. I've seen news footage of him striking tough poses behind a podium, glaring at the audience, cursing into microphones, screaming at huge crowds to "fight it out," and "knock the motherfuckers who control this thing right on their ass!"

That man bears no resemblance to the Jeff I know, who absolutely never shows anger or impatience, who wears a tie to work every day, and is so mellow, so ... parental.

My father's own parents had been Southern-California Quakers. His father, Al, was a conscientious objector who spent World War II in an isolated work camp in the mountains. Jeff was a blond, sunny kid; the recognizable precursor to the adult I know now. He was a go-getter-Boy of the Year-a committed participant in numerous organizations. He hiked and camped throughout Southern California. He left for Antioch College in 1965, just as the war in Vietnam was becoming national news. His whole upbringing had prepared him to oppose the violence of the conflict, and within six weeks he had joined the local chapter of Students for a Democratic Society-at a time when the national organization had just a few thousand members.

War and antiwar escalated together. During his sophomore year, Jeff dropped out to take a full-time organizing job as regional director for SDS in New York City. The next year he sat-in at the Pentagon with 60,000 others. By 1968, there were half a million U.S. troops in Vietnam, and SDS reckoned on roughly the same number of student supporters back home. Tactics had changed. In the early demonstrations, marchers had allowed themselves to be arrested, going limp when the police arrived. It was a measure of how far things had degenerated that, at the Democratic Convention in Chicago, protesters and police engaged in running street fights for an entire week.

By 1969, Jeff had spent four years working against the war. He had been arrested a dozen times for protesting, but what had he accomplished? The conflict was expanding into other South-East Asian countries. Though his Quaker lineage had earned him conscientious-objector status, he had long since abandoned his father's teachings. Jeff believed that the Vietnamese had a right to defend themselves with violence, so he wrote to Selective Service and asked to be removed from the ranks of pacifists.

Here is where the picture starts to change. Jeff aligned himself with Weatherman, one of several factions bidding for power at the SDS summer convention, and was elected to a top leadership position. He immediately began organizing for a new kind of demonstration where, instead of avoiding conflict, the protesters would set out to fight the police. Scheduled for October, the riot would come to be known as the Days of Rage.

This was the period - the months building up to October — when my father really becomes unrecognizable to me. Preparing for the confrontation, he and the others went a little mad. In control of the SDS printing press, they transformed the newsletter from New Left Notes into Fire! and ran off a few issues before losing interest. SDS had been the framework for all Jeff's political activities since 1965, but it was defunct within a few months of his taking over. He didn't mourn. He was in training, practicing karate, critiquing others' commitment.

He believed the world was in a phase of revolution and he was willing to sacrifice to be a part of it. Weatherman's goal was to show solidarity with third-world people by forming a white fighting-force inside the imperialist mother country. They wanted ten thousand furious rioters to come to the Days of Rage, but it was soon clear they'd get nothing like so many. Jeff drove to Madison, Wisconsin, and crashed a meeting at the University. While his cohorts 
struck karate poses behind him, Jeff pushed the speaker away, grabbed the mic, and yelled, "You don't see any motherfucking students at any motherfucking college up here on this stage. All of us up here are stone communist revolutionaries." Every person in the room — in unison - turned their chairs around to face the other direction. After that, Jeff pushed harder, turning on the students who were his base, castigating them, humiliating them for faltering. Nothing but total dedication was acceptable. My father made more enemies in these few months than in all the other seasons of his life.

On October 8, 1969, a few hundred protesters gathered around a bonfire in Chicago's Lincoln Park. Jeff, his hair dyed brown, led them on a rampage through the city's downtown shopping district. For a few unbelievable minutes they were in charge, smashing store windows and destroying cars. Then the police regrouped, formed a line, and waited. Jeff charged ahead, ducked a punch and slipped through the barricade, but a block later he was cornered by half a dozen plainclothes cops. They kicked him, maced him, chucked him in a paddy wagon.

By Sunday, it was finished. Some glass had been broken. Dozens of demonstrators had been arrested, eight had been shot by police. A few cops had gone to the hospital with minor injuries. One lawman had been paralyzed while attempting to throw a football tackle at a protester. All the leaders of Weatherman had been arrested and were facing federal and state charges. The FBI and police tailed them constantly. Almost nobody in the New Left had supported the misadventure. The alternative press dedicated full pages to critiquing the Weatherman strategy. Even Fred Hampton, leader of the Black Panthers in Chicago, had denounced the action, saying, "It's Custeristic in that its leaders take people into situations where the people can be massacred, and they call that revolution. That's nothing but child's play. It's folly."

The Days of Rage — a frontal assault against a superior force-had been a tactical disaster. Seeking an alternative strategy, Jeff and the others went to the opposite extreme: clandestinity, secrecy, sustainability. They started constructing the underground. At first, they resented those who had stayed away from Chicago. But, after the Townhouse Explosion — when three close friends were killed-Jeff and the others dropped the anger and fashioned a more compassionate guerrilla army.

Jeff started to become his recognizable self again. The communiqués from the underground lost their macho edge. In the New Morning statement of autumn 1970, they criticized their earlier steeliness, and celebrated the softer side of the hippie culture: "free wild children," and "organic food." Clearly, Jeff had returned to the things I know him for: communing with birds, taking nature hikes. Wherever he was-it would take the FBI eleven more years to find him — it was the countryside, and he belonged there.

So, if the teenage Jeff was clearly the Jeff I know, and the underground Jeff was too, then who was that man whose picture I've seen — the Jeff Jones of 1969 and 1970? The Vietnam War and his immersion in the fight against it had transformed him into someone else. He had determined that violent protest was not just valid, but that it was the only tactic, and since he was committed to the antiwar movement he would have to use it himself. The result-for him and the others-was an out-of-body experience.

The antiwar demonstrators - even the Weathermen - were always the least violent factor in the equation. Their street fights and tiny explosives were a joke compared to the clubbings of the police, the carpet-bombings of the military, and the warfare of the Vietnamese. These people were pacifistic by nature. They had no history of violence. They turned themselves inside-out, found the will to fight the police. Got their asses kicked. Earned the scorn of their former comrades.

Yet, they did it.

And because they did, the Days of Rage protest is in the history books. Had it never happened, what proof would there be that even middle-class white Americans, faced with sufficient provocation, will take to the street with pipes and clubs and transform themselves, for a weekend at least, into stone communist revolutionaries? 